\title{
Seasonal Variation of the Hydro-Environmental Factors and Phytoplankton Community around Waters in Tincan Island, Lagos State, Nigeria
}

\author{
${ }^{1}$ OKERE, MC; *2DAVIES, IC; ${ }^{2}$ OKONKWO, SE \\ ${ }^{*}$ Department of Marine Sciences, Faculty of Science, University of Lagos, Akoka, Lagos State, Nigeria \\ ${ }^{2}$ Department of Fisheries, Faculty of Agriculture, University of Port Harcourt, P.M.B. 5323, Port Harcourt, \\ Nigeria. \\ *Corresponding Author Email: davies.chris@uniport.edu.ng; Tel: +234 7038825990
}

\begin{abstract}
The phytoplankton diversity, pigment, abundance and distribution in relation to physico-chemical parameters were studied from four stations for a period of five months (May - September 2018) and were analysed using standard procedures. Rainfall was highest $(329.5 \mathrm{~mm})$ in September and lowest $(142.7 \mathrm{~mm})$ in July. The total suspended solid (TSS) had a mean value of $63.10 \pm 12.81 \mathrm{mg} / \mathrm{L}$ and the total dissolved solids (TDS) had the highest value of 15189 $\mathrm{mg} / \mathrm{L}$ in May which was not significantly different around the sampling points $\{\mathrm{P}>0.05\}$. The $\mathrm{pH}$ and nitrate level recorded had a mean value of $7.25 \pm 0.33$ and $3.11 \pm 1.33 \mathrm{mg} / \mathrm{L}$ respectively. Microscopic identification revealed a total of 129 species belonging to 62 genera, 22 families and five divisions in the following order of specie abundance: Bacillariophyceae (65 taxa) > Cyanophyceae $(27$ taxa) $>$ Chlorophyta $(20$ taxa $)>$ Dinophyceae $(10$ taxa $)>$ Euglenophyceae (7 taxa). The high dominance of Microcystis aeruginosa observed was indicative of organic pollution. The range of community structure indices were as follows: Margalef Index $(0.1406-5.295)$ and Shannon - Weiner Index $(0.02644-0.4979)$. The relatively high nutrient status favours the high abundance of phytoplankton which is understood to be deleterious to the ecosystem. Municipal wastes must be treated or recycled before discharge and a continuous environmental surveillance is required to maintain the biological integrity of this area.
\end{abstract}

\section{DOI: https://dx.doi.org/10.4314/jasem.v24i10.6}

Copyright: Copyright $(\mathcal{C} 2020$ Okere et al. This is an open access article distributed under the Creative Commons Attribution License (CCL), which permits unrestricted use, distribution, and reproduction in any medium, provided the original work is properly cited.

Dates: Received: 15 August 2020; Revised: 22 September 2020; Accepted: 19 October 2020

Keywords: Phytoplankton, Physicochemical Parameters, Nutrient Status and Tincan Island

In the quest to evaluate the ecological integrity of the waters around the Tincan Island, the need to study the phytoplankton community is of prime importance. This can be done when environmental monitoring of the area is carried out which helps in highlighting the effect of land based anthropogenic stressors. Phytoplankton are unicellular organisms that carry out oxygenic photosynthesis, they live in the upper illuminated waters of all aquatic ecosystems (Maranon, 2009). They produce almost 70 percent of world's atmospheric oxygen and accounts for half of all photosynthesis on Earth (Thurman, 2007). They serve as a source of important information on the state and functioning of river ecosystems (Kelly et al., 2008) and also provide unique information concerning ecosystem's conditions for instance, its abundance and composition can be an excellent indicator to environmental changes (Varadharajan and Soundarapandian, 2014). Phytoplankton primary production along the continental margins is tightly linked to variability of water quality, biogeochemical processes including ocean - atmosphere $\mathrm{CO}_{2}$ exchange, and production at higher trophic levels including species harvested as food (Cloern et al., 2014). It can also be an indicator for changes in marine ecosystems responding to environmental changes (Wassman et al., 2011; Arrigo and van Dijken, 2015). Each phytoplankton specie has a different set of favourable conditions that promote its growth and reproduction therefore they are of great importance in bio-monitoring pollution (Davies, 2009). It is important to understand phytoplankton production which is key in understanding variability of ecosystem respiration and metabolism; cycling of nutrients, carbon, and trace metals; water and habitat quality; secondary production by herbivores; fish catch; production of cultured shellfish; and the cumulative value of all these ecosystem services, judged to be highest in estuaries among all biomes (Costanza et al., 1997). According to Durrieu et al. (2011), microalgae are used as a sensitive indicator for environmental changes, as well as a biological sensor for the potentially toxic effects of heavy metals. They are of great ecological and economic importance as it is the base of aquatic food webs and fisheries (Castellani, 2009). Some aquatic creatures help limit or reduce phytoplankton populations by feeding on them. Filterfeeding oysters, scallops and sponges consume phytoplankton as they circulate seawater through their bodies, while microscopic crustaceans like copepods 
graze on phytoplankton in the water column. Anthropogenic activities impact the phytoplankton community which are crucial primary producers because a healthy population of this important set of organisms is essential to maintain the balance in the ecosystem. These activities can cause changes in the biotic species type and abundance which can eliminate intolerant species (Onyema, 2007). A healthy phytoplankton community maintains the integrity of an aquatic food web. This is because it forms the bulk of the nutrients required by higher trophic organisms. When phytoplankton communities are threatened, the aquatic biodiversity endemic in the area are at risk of depletion or extinction. The aim of this study is to determine the phytoplankton productivity through evaluating its characteristics around the waters of the Tincan Island and also to investigate how it is affected by ecological parameters

\section{MATERIALS AND METHODS}

Study site: The waters around Tincan Island (fig 1) are important water bodies which serve as a viable resource for artisanal and commercial fishing as well as transportation.

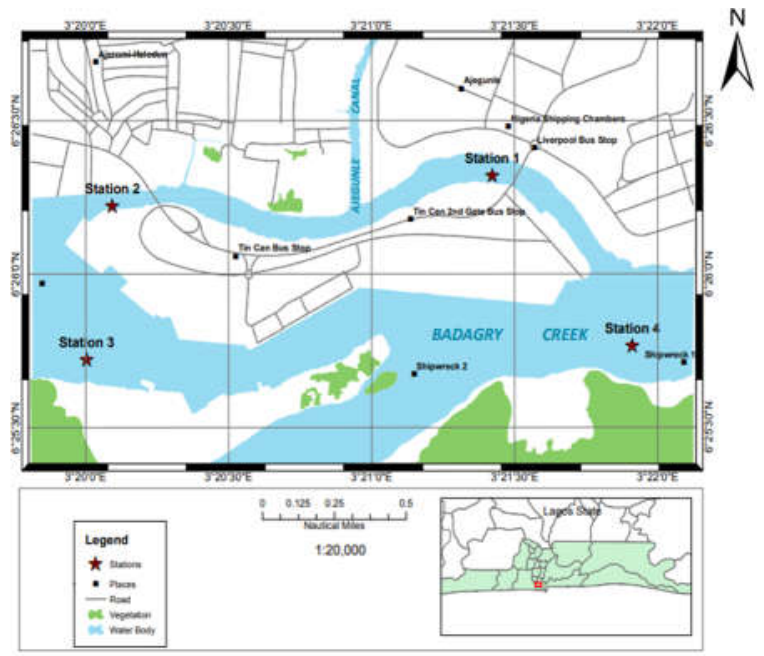

Fig 1: Tincan Island area showing the Ajegunle and Badagry Creek

It receives input from the Ajegunle creek, Tincan Island creek, Badagry creek, Porto-Novo creek, FESTAC creek as well as the Tomaro and Lighthouse creek. The adjoining waters are heavily contaminated due to the wanton activities of sand miners, dredgers, discharge of untreated sewage and the relatively unregulated activities of ships and other vessels. The Badagry and Tincan Island creeks are sheltered tidal creeks located inland along the lower part of the western Lagos harbour at Apapa and Tincan island.

Collection of Samples: Water samples were collected once monthly from four stations between May September 2018. These samples were collected using $75 \mathrm{cl}$ plastic containers with each indicating the month of collection at the study site. The plastic bottles were dipped $20 \mathrm{~cm}$ into their respective study points and were carefully preserved in ice-chest for physical and chemical analysis. Plankton samples were also collected simultaneously. The plankton samples were collected by using a plankton net of $55 \mu \mathrm{m}$ mesh size with a sample bottle attached to a motorized boat at an interval of 15 minutes while the boat is almost stationary. The filtrate in the attached sample bottle was transferred into a well labelled plastic container. The plankton samples were preserved in diluted $10 \%$ formalin and transported to the laboratory for microscopic investigation.

Determination of Biomass Using Chlorophyll a $(\mathrm{mg} / \mathrm{L}): 200 \mathrm{~mL}$, each of de-ionized water (blank) and samples $\left(\mathrm{V}_{\text {filtered }}\right)$ were filtered through $0.45 \mu \mathrm{m}$ glass fibre filters. Each filter was removed and placed in labelled polypropylene tubes. To each tube was added $3 \mathrm{ml} \mathrm{90 \%} \mathrm{acetone} \mathrm{solution,} \mathrm{and} \mathrm{macerated} \mathrm{at} 500 \mathrm{rpm}$ for $1 \mathrm{~min}$, steeped in the dark for $2 \mathrm{hrs}$ at $4^{\circ} \mathrm{C}$ and clarified by filtration and then adjusted to $20 \mathrm{ml}$ $\left(\mathrm{V}_{\text {extract }}\right)$ with $90 \%$ acetone solution. The extract was capped and then store in the dark until analysed. $3 \mathrm{ml}$ of the clarified sample extract was transferred to a cuvette and the absorbance measured at 750, 665, 664, 647 and $630 \mathrm{~nm}$, using a spectrophotometer $(\mathrm{HACH}$ DR 3900). Thereafter, the extract in the cuvette was acidified with $0.1 \mathrm{ml}$ of $0.1 \mathrm{MHCl}$ solution, gently agitated and allowed to stand for $90 \mathrm{sec}$. The absorbance of the acidified extract was read at 750 and at $665 \mathrm{~nm}$. Test results were validated with chlorophyll calibration standards $(5-20 \mathrm{ug} / \mathrm{L})$. The pigments concentrations were calculated as follows:

$$
\begin{gathered}
\operatorname{Ch}(\mathrm{a})=\frac{26.7 *(\mathrm{~A} 664 \mathrm{~b}-\mathrm{A} 665 \mathrm{a}) * \mathrm{~V}_{\text {extract }}}{\mathrm{V}_{\text {filtered }} * \mathrm{~L}} \\
\mathrm{Ph}(\mathrm{a})=\frac{26.7 *[1.7(\mathrm{~A} 665 \mathrm{a}-\mathrm{A} 664 \mathrm{~b})] * \mathrm{~V}_{\text {extract }}}{\mathrm{V}_{\text {filtered }} * \mathrm{~L}} \\
\operatorname{Ch}(\mathrm{b})=\frac{21.03 *(\mathrm{~A} 647 \mathrm{~b})-5.43 *(\mathrm{~A} 664 \mathrm{~b})-2.66 *(\mathrm{~A} 630 \mathrm{~b}) * \mathrm{~V}_{\text {extract }}}{\mathrm{V}_{\text {filtered }} * \mathrm{~L}}
\end{gathered}
$$


Where: Ch(a) = Chlorophyll- $a$ [corrected; $(\mu \mathrm{g} / \mathrm{L})]$; $\mathrm{Ph}(\mathrm{a})=$ Phaeophytin $-a(\mu \mathrm{g} / \mathrm{L}) ; \mathrm{Ch}(\mathrm{b})=$ Chlorophyll- $b$ $(\mu \mathrm{g} / \mathrm{L}) ; V_{\text {extract }}=$ volume of extract $(\mathrm{mL}) ; V_{\text {filtered }}=$ volume of sample filtered (L); $L=$ light path length or width of cuvette, cm; 664b, 647b, 630b = corrected absorbance of extract before acidification; $665 a=$ corrected absorbance of extract after acidification; The value 26.7 is the absorbance correction factor $(A \times K$; $A=$ absorbance coefficient for chlorophyll $a$ at $664 \mathrm{~nm}$ $=11.0 ; K=$ ratio expressing correction for acidification $=2.43$

Determination of Biomass in Terms of Numbers Using Counting Methods (per $\mathrm{ml}$ ): Plankton sample was allowed to settle in the lab for $2 \mathrm{hrs}$ and concentrated to $20 \mathrm{ml}$. For each settled sample, 5 drops of well mixed sample was investigated. On each occasion, one drop of sample was thoroughly investigated using the Drop Count Method. For each drop five transect were investigated by moving the stage at different positions under a Carl Zeiss monocular microscope.

Phytoplankton species were observed, identified and drawn using text. Photomicrographs of phytoplankton were taken under a Microstar IV Photomicroscope (x 40 eyepiece) on Ilford 100 black and white film. Several relevant keys and illustrations: (Winpenny, 1966; Compère, 1976a, 1976b, 1977b; Tomas, 1997) were adequately consulted to confirm identification.

Determination of Community Structure Analysis: Species diversity index (d), (Shannon and Wiener, 1963), Species richness (d) (Margalef, 1951), Evenness or equitability indices (j) (Pielou, 1975) and Taxa_S were used to estimate the phytoplankton biodiversity.

Determination of Species Diversity Index (d): This is also known as the species diversity index. The species richness (Margalef, 1951) was given by the following equation:

$$
\mathrm{d}=\frac{\mathrm{S}-1}{\operatorname{In} \mathrm{N}}
$$

Where $\mathrm{d}=$ Margalef richness index or species diversity index; $\mathrm{S}=$ Number of species in the population; $\mathrm{N}=$ Total number of individuals in species.

Determination of Shannon and Wiener Diversity Index (Hs): This was proposed by Shannon and Wiener (1963) and it is given by the equation:

$$
\mathrm{H}_{\mathrm{s}}=\frac{\mathrm{N} \log \mathrm{N}-\left(\sum \mathrm{P}_{\mathrm{i}} \log \mathrm{P}_{\mathrm{i}}\right)}{\mathrm{N}}
$$

Where Hs = Shannon-Wiener diversity index; $\Sigma=$ Summation; $i=$ count denoting $i^{\text {th }}$ species ranging from 1 to $\mathrm{n} ; \mathrm{i}=$ proportion that the $\mathrm{i}^{\text {th }}$ species represent to the total number of individuals in the Sampling space.

Determination of Equitability (j): Species equitability or evenness (Pielou, 1996) was determined by the equation:

$$
\mathrm{j}=\frac{\mathrm{Hs}}{\log _{2} \mathrm{~s}}
$$

Where $\mathrm{j}=$ equitability index; Hs = Shannon-Wiener diversity index; $S=$ number of species in the population.

\section{RESULTS AND DISCUSSION}

The hydrodynamic nature of lagoons and mangrove creek ecosystems are important in governing the distribution and occurrence of phytoplankton forms within wetland ecosystems. The data generated from this study has shown that species recorded have been previously recorded in the Nigerian coastal environment and are therefore known endemic species.

During the sampling period, a total of 129 phytoplankton taxa, belonging to five groups, were recorded in waters around Tincan Island. Bacillariophyceae was the most diverse class (66 sp.), followed by Cyanophyceae (27 sp.), Chlorophyceae (20 sp.), Miozoa (10 sp) and Euglenophyceae (7 sp.). In this investigation, members of Cyanophyta were the most common species and it was predominated with Microcystis aeruginosa which lives in high organic pollution condition (Onyema, 2013). Phytoplankton serve as sensitive indicators of environmental changes in the aquatic ecosystem as well as a biological sensor for detecting potentially toxic effects of some heavy metals (Durrieu et al., 2011).

The variability of phytoplankton species composition can be attributed to accumulative effect of the different environmental conditions. The enhanced population densities of phytoplankton can be attributed to the physicochemical parameters obtained. In addition, phytoplankton species have different resource for nutrition requirements and responses to the physicochemical characteristics of the aquatic ecosystem, thus causing variations in the phytoplankton composition. 
Seasonal Variation of the Hydro-Environmental Factors.....

Table 1: Mean monthly variation in physicochemical parameters

\begin{tabular}{llllll}
\hline Physicochemical Parameters & May & June & July & August & September \\
\hline Rainfall $(\mathrm{mm})$ & 275.6 & 236.2 & 142.7 & 257.6 & 329.5 \\
pH $@ 2^{\circ} \mathrm{C}$ & 7.295 & 7.325 & 7.325 & 7.3625 & 6.9425 \\
Conductivity $(\mu \mathrm{S} / \mathrm{cm})$ & 20730 & 12567.5 & 12567.5 & 13347.6 & 3702.575 \\
TSS $(\mathrm{mg} / \mathrm{L})$ & 13.25 & 10 & 10 & 9 & 30.5 \\
TDS $(\mathrm{mg} / \mathrm{L})$ & 12560.5 & 7591.325 & 7591.325 & 8089.98 & 2200.85 \\
Turbidity $(\mathrm{NTU})$ & 5.71 & 10.3475 & 10.3475 & 13.475 & 35.5575 \\
Salinity $\left(\mathrm{ppt}\right.$, at $\left.25^{\circ} \mathrm{C}\right)$ & 12.36 & 7.1975 & 7.1975 & 7.66 & 2.0025 \\
Total Hardness $\left(\mathrm{mg} / \mathrm{L}\right.$, as $\left.\mathrm{CaCO}_{3}\right)$ & 2266.03 & 1308.55 & 1308.55 & 1395.48 & 378.25 \\
Dissolved Oxygen $(\mathrm{mg} / \mathrm{L})$ & 4.3 & 4.99 & 4.99 & 4.845 & 2.9175 \\
Biochemical Oxygen Demand5 $(\mathrm{mg} / \mathrm{L})$ & 31 & 27.25 & 27.25 & 20.75 & 59.5 \\
COD $(\mathrm{mg} / \mathrm{L})$ & 233.5 & 122 & 122 & 66.25 & 462.25 \\
Chloride $(\mathrm{mg} / \mathrm{L})$ & 6749.33 & 3924.65 & 3924.65 & 4171.08 & 1086.475 \\
Nitrate $\left(\mathrm{mg} / \mathrm{L}\right.$, as NO $\left.{ }^{3-}\right)$ & 4.78 & 3.0225 & 3.0225 & 2.5075 & 2.215 \\
Phosphate $\left(\mathrm{mg} / \mathrm{L}\right.$, as PO $\left.{ }^{3-}\right)$ & 1.525 & 0.3975 & 0.3975 & 0.8 & 0.4475 \\
DIP $(\mathrm{mg} / \mathrm{L})$ & 0.5085 & 0.1585 & 0.1585 & 0.267 & 0.14925 \\
DIN $(\mathrm{mg} / \mathrm{L})$ & 1.07975 & 0.6815 & 0.6815 & 0.566 & 0.5 \\
DON $(\mathrm{mg} / \mathrm{L})$ & 0.4815 & 0.919 & 0.919 & 0.77875 & 0.90525 \\
\hline Biological Parameters & & & & & \\
\hline Chlorophyll $a(\mu \mathrm{g} / \mathrm{L})$ & 4.775 & 3.6 & 3.6 & 2.5 & 3.95 \\
Chlorophyll $b(\mu \mathrm{g} / \mathrm{L})$ & 0.225 & 0.425 & 0.425 & 0.4 & 0.375 \\
Pheophytin $(\mu \mathrm{L} / \mathrm{L})$ & 0.125 & 0.175 & 0.175 & 0.175 & 0.175 \\
\hline \hline
\end{tabular}

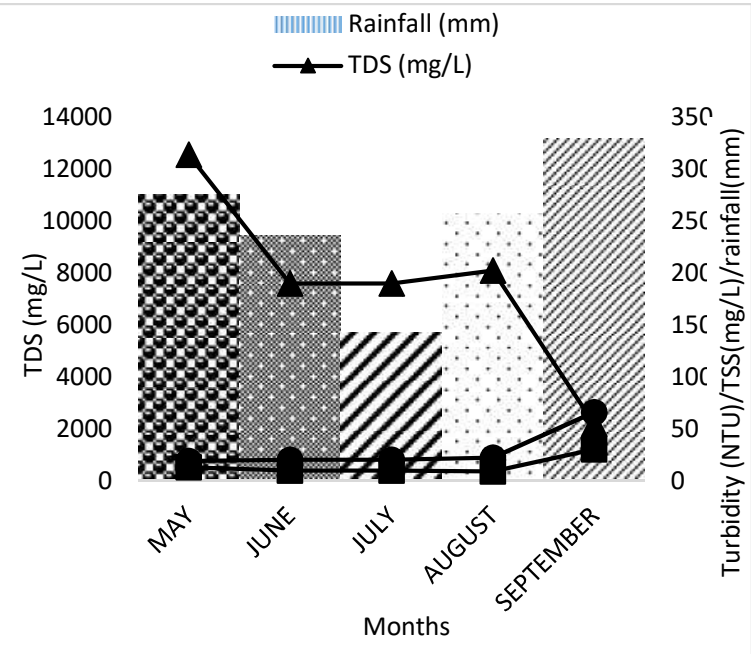

Fig 2: Mean monthly variations in TDS, TSS, Turbidity and Rainfall around the study area (May - September, 2018).

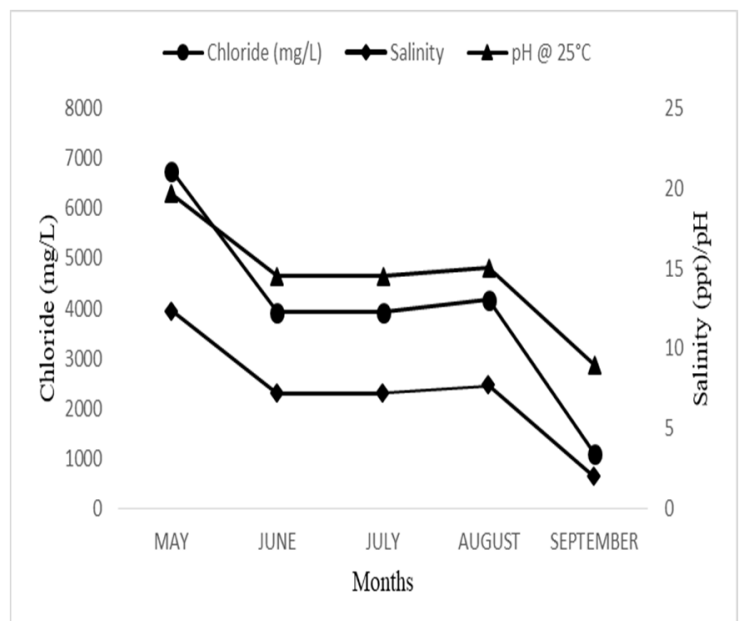

Fig 3: Monthly variations in Chloride, Salinity and $\mathrm{pH}$ around the study area (May - September, 2018.

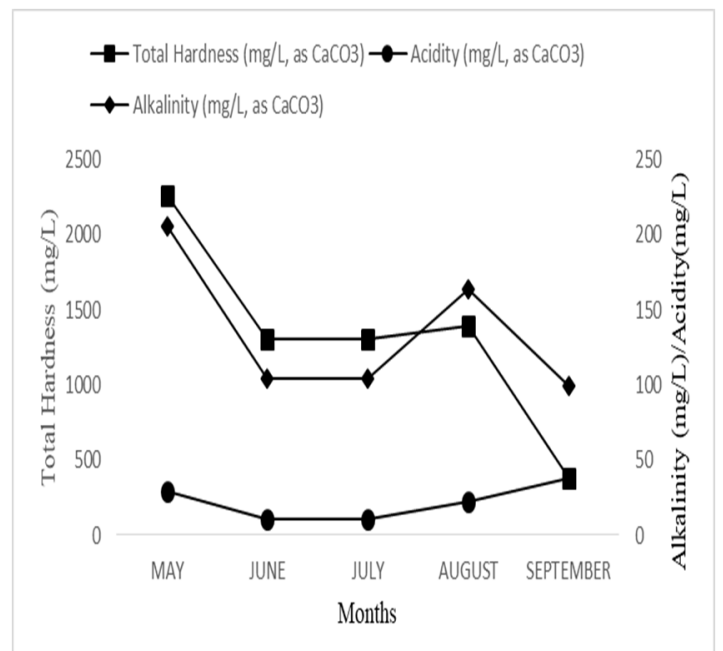

Figure 4: Mean monthly variation in Total hardness, alkalinity and acidity around the study area (May - September, 2018).

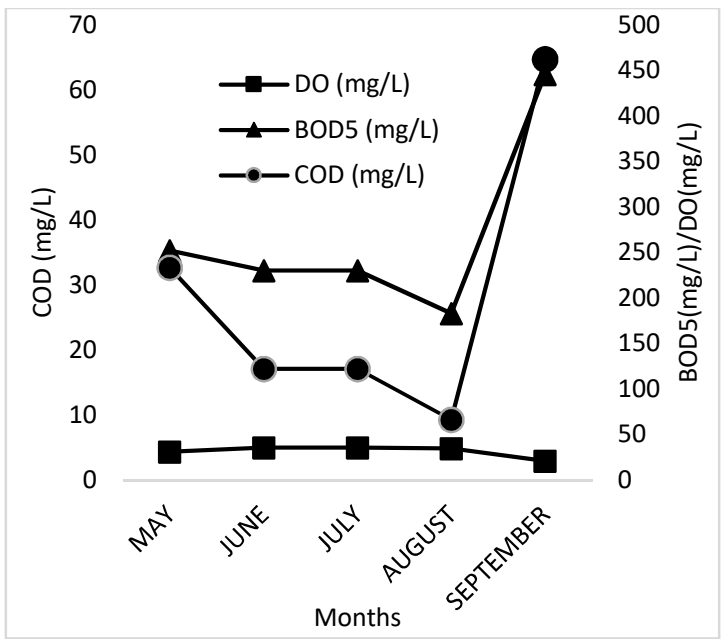

Figure 5: Mean monthly variation in $\mathrm{COD}, \mathrm{DO}$ and $\mathrm{BOD}_{5}$ around the study area (May - September, 2018) 


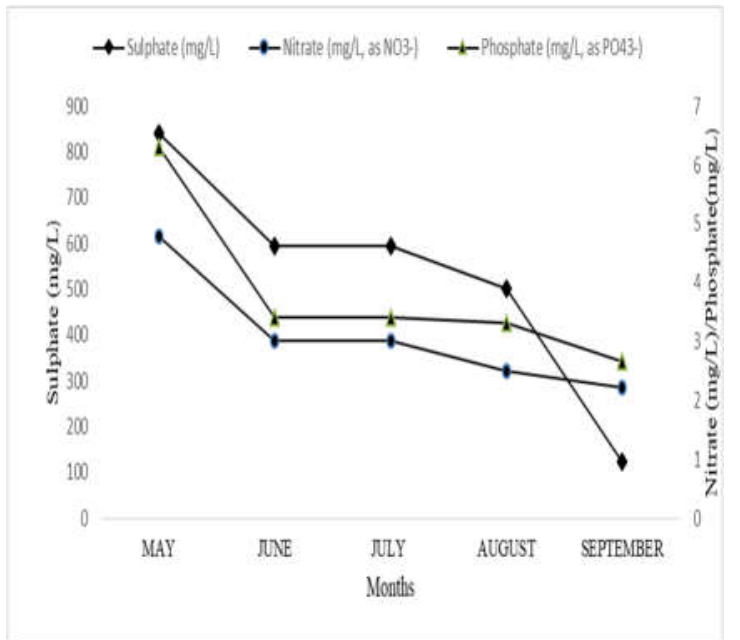

Fig 6: Mean monthly variation in sulphate, nitrate and phosphate around the study area (May - September, 2018).

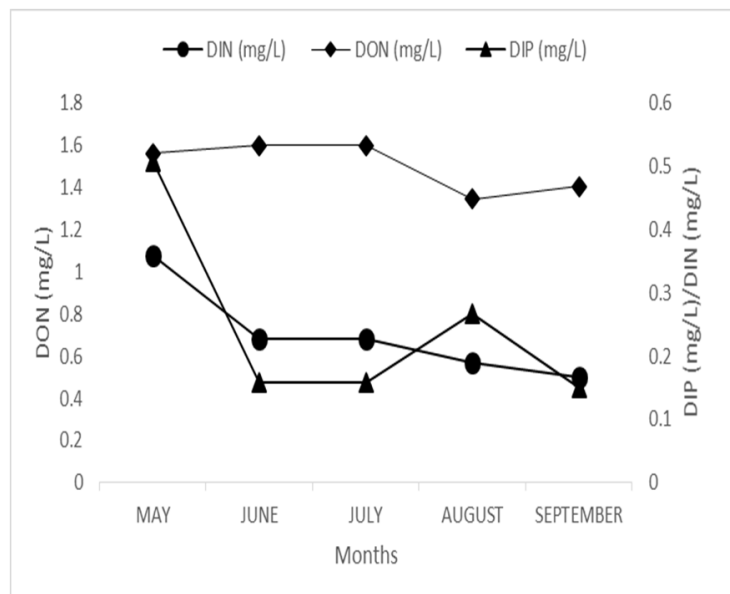

Fig 7: mean monthly variation in DON, DIP and DIN around the study area (May - September, 2018).

Biological Parameters: Chlorophyll a $(\mathrm{mg} / \mathrm{L})$ : Chlorophyll a showed variation with values ranging from 1 to $7.5 \mathrm{mg} / \mathrm{L}$. The minimum value $1 \mathrm{mg} / \mathrm{L}$ was recorded in the month of August and September while the maximum value $7.5 \mathrm{mg} / \mathrm{L}$ was recorded in the month of May. The mean value of chlorophyll a during the sampling period was $3.69 \pm 1.88 \mathrm{mg} / \mathrm{L}$.

Chlorophyll $b \quad(\mathrm{mg} / \mathrm{L})$ : Chlorophyll $\mathrm{b}$ showed variations with values ranging from 0.1 to $0.7 \mathrm{mg} / \mathrm{L}$. The minimum value $0.1 \mathrm{mg} / \mathrm{L}$ was recorded in the month of May while the maximum value $0.7 \mathrm{mg} / \mathrm{L}$ was recorded in the month of June, July and August. The mean value of chlorophyll $\mathrm{b}$ during the sampling period was $0.37 \pm 0.18 \mathrm{mg} / \mathrm{L}$.

Biological Characteristics: The phytoplankton spectrum was represented by five divisions respectively Bacillariophyta, Cyanophyta and Chlorophyta, Euglenophya and Miozoa.

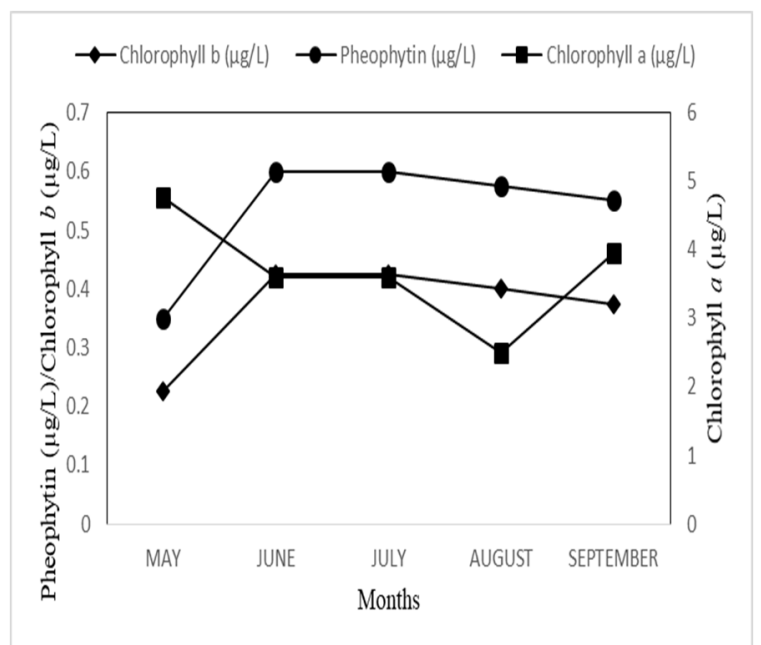

Fig 8: mean monthly variation in chlorophyll $a$, pheophytin and chlorophyll $b$ around the study area (May - September, 2018).

The division Bacillariophyta was the most diverse of the five classes, making up about 51 percent of the total population diversity while the division Cyanophyta makes up about 21 percent, Division Chlorophyta makes up about $15 \%$, Division Euglenophyta makes us about $5 \%$ and Division Miozoa made up about $8 \%$. The centric and pennate diatoms were the most abundant of the total phytoplankton with the most occurring ones being Microcystis aeruginosa, cyclotella meneghiniana and Nitzchia obtusa, Cyanophyta was represented by organisms which include: Oscillatoria lininosa, Spirulina platensis and Chroococcus sp. Chlorophyta was also represented by organisms like Gomphosphaeria aponina, Chlorella sp. and Desmodesmus sp.

Correlation Coefficient (r): The values shown in table 2 indicates that the physicochemical parameters correlates positively across stations

Table 2: Correlation coefficient across stations

\begin{tabular}{lllll}
\hline & St. 1 & St. 2 & St. 3 & St. 4 \\
\hline St. 1 & 1 & & & \\
St. 2 & 0.997971 & 1 & & \\
St. 3 & 0.997948 & 0.99999 & 1 & \\
St. 4 & 0.998117 & 0.999893 & 0.999828 & 1 \\
\hline
\end{tabular}

Biodiversity Indices/Community Structure: Margalef (d): The species richness index (d) was highest in the month of June with a value of 5.295 and lowest in August with a value of 0.1406 . (Mean value of $1.59 \pm$ 1.53)

Shannon - Wiener Index / Diversity Index (Hs): The Shannon-Wiener index was highest with a value of 0.5554 recorded in the month of September while the 
lowest value was recorded in the month of August with a value of 0.02644 and a mean value of $0.23 \pm 0.18$

Species Evenness or Equitability (j): The species evenness or equitability $(j)$ was highest in the month of May with a value of 0.2266 and it was lowest in the month of August with a value of 0.02837 and a mean value of $0.09 \pm 0.06$

Taxa: The Taxa was highest with a value of 37 recorded in the month of June while the lowest value was recorded in the month of August with a value of 2 with a mean value of $14.00 \pm 13.43$.

Individuals: The Individuals value indicated that had a highest value in the month of June with 6040 and the lowest with value of 1230 in the month of August at the sampling site and a mean value of $2962.25 \pm$ 1703.25

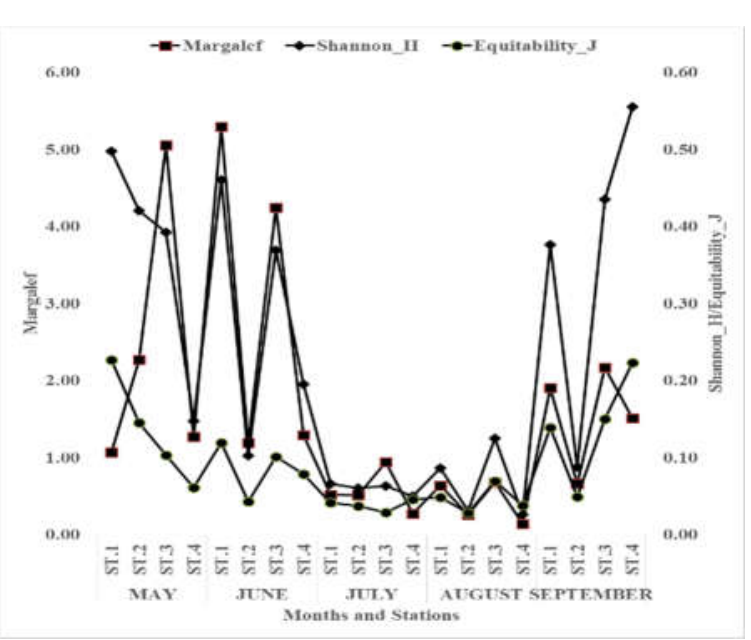

Figure 9: Monthly variation in Margalef, Shannon and Equitability around the study area (May September, 2018).

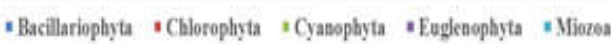
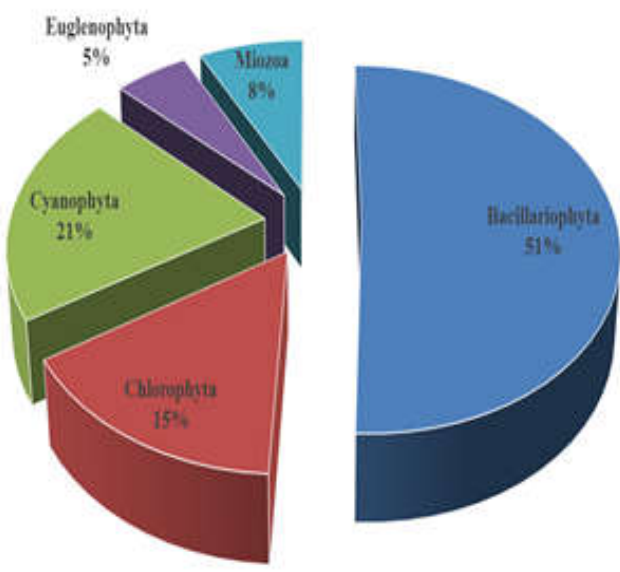

Fig 10: Percentage species diversity of phytoplankton divisions around the study area (May - September, 2018)

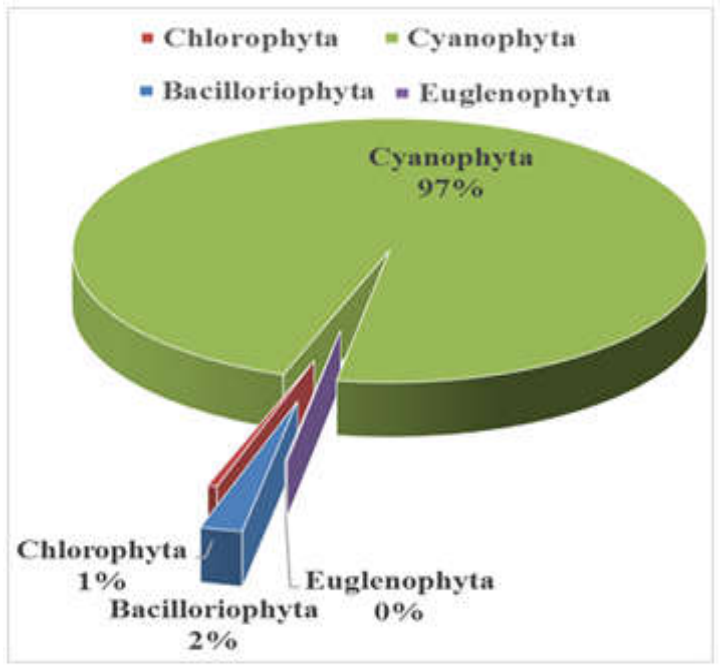

Fig 11: Percentage species abundance of phytoplankton divisions around the study area (May - September, 2019

Table 3A: Diversity Index Determined Using PAST for May, June and July

\begin{tabular}{l|llllllllllll}
\hline & \multicolumn{4}{|c}{ MAY } & \multicolumn{1}{c}{ JUNE } & \multicolumn{4}{c}{ JLY } \\
\hline & St. 1 & St. 2 & St. 3 & St. 4 & St. 1 & St. 2 & St. 3 & St. 4 & St. 1 & St. 2 & St. 3 & St. 4 \\
Taxa_S & 9 & 18 & 45 & 11 & 47 & 11 & 37 & 12 & 5 & 5 & 9 & 3 \\
Individuals & 1765 & 1805 & 6015 & 2665 & 5925 & 4385 & 6040 & 4895 & 2125 & 2365 & 4965 & 1310 \\
Shannon_H & 0.5 & 0.42 & 0.39 & 0.15 & 0.46 & 0.1 & 0.36 & 0.2 & 0.07 & 0.06 & 0.06 & 0.05 \\
Margalef & 1.07 & 2.27 & 5.06 & 1.27 & 5.3 & 1.19 & 4.14 & 1.3 & 0.52 & 0.51 & 0.94 & 0.28 \\
Equitability_J & 0.23 & 0.15 & 0.1 & 0.06 & 0.12 & 0.04 & 0.1 & 0.08 & 0.04 & 0.04 & 0.03 & 0.05 \\
\hline
\end{tabular}

Table 3B: Diversity Index Determined Using PAST for August and September

\begin{tabular}{lllllllllll}
\hline & \multicolumn{1}{c}{ AUGUST } & \multicolumn{1}{c}{ SEPTEMBER } \\
\hline & St. 1 & St. 2 & St. 3 & St. 4 & St. 1 & St. 2 & St. 3 & St. 4 & Mean & SD \\
Taxa_S & 6 & 3 & 6 & 2 & 15 & 6 & 18 & 12 & 14.00 & 13.43 \\
Individuals & 2400 & 2285 & 1560 & 1230 & 1570 & 1985 & 2505 & 1450 & 2962.25 & 1703.25 \\
Shannon_H & 0.09 & 0.03 & 0.13 & 0.03 & 0.38 & 0.09 & 0.44 & 0.56 & 0.23 & 0.18 \\
Margalef & 0.64 & 0.26 & 0.68 & 0.14 & 1.9 & 0.66 & 2.17 & 1.51 & 1.59 & 1.53 \\
Equitability_J & 0.05 & 0.03 & 0.07 & 0.04 & 0.14 & 0.05 & 0.15 & 0.22 & 0.09 & 0.06 \\
\hline \hline
\end{tabular}


The increasing phytoplankton abundance may be attributed to high concentrations of organic wastes and high level of both $\mathrm{N}$ and $\mathrm{P}$ in accordance with the agricultural and domestic sewage discharged from nearby settlements. Onyema et al (2013), reported the presence of some phytoplankton species such as Navicula sp. and Nitzchiz sp., the complexity of aquatic ecosystems and the linkages within them can make the effect of disturbances on them difficult to predict. These linkages mean that damage to one component of the ecosystem can lead to impacts on other ecosystem components. Increasing our understanding of aquatic ecosystems can lead to better practices that minimize impacts on aquatic environments. Much effort in water resource management is directed at optimizing the use of water and in minimizing the environmental impact of water use on the natural environment. Management of any aquatic ecosystem requires accurate for available knowledge, the uses to which it may be put, the competing demands for the resource, measures to and processes to evaluate the significance and worth of competing demands and mechanisms to translate policy decisions into actions on the ground.

Algae play an important role in controlling and biomonitoring of organic pollutants in aquatic ecosystems. It have used in biological purification of wastewater, accumulate nutrients, heavy metals, pesticides, organic and inorganic toxic substances, and radioactive matters. Evaluating phytoplankton diversity is an important step in the determination of the health status of the aquatic ecosystem. This diversity may be a product of all spatial and temporal changes affecting the community. Due to the input of organic substances, effect of rainfall, saltwater incursion and the apparent effect of tides, the phytoplankton status of the waters may alter, therefore, constant monitoring of the aquatic ecosystem is important.

The structure of the phytoplankton community is a good method of assessing the quality and stability of an aquatic ecosystem at various scales. Therefore, more research should be encouraged in this seemingly simple but significant bio-assessment method, phytoplankton communities may be used as an indicator of ecological status.

Conclusion: The physicochemical data obtained were within limits as recommended by NESREA for tropical aquatic life. The observed variations in the parameters can be attributed to rainfall patterns and anthropogenic activities which consequently have a direct implication on the phytoplankton community and structure.

\section{REFERENCES}

American Public Health Association (APHA) and American Water Works Association and Water Pollution Control Federation (2005). Standard Methods for the Examination of Water and Waste Water, 21st Edition. APHA, Washington. 1195pp.

Arrigo, K. R.; Van Dijken, G. L. (2015). Continued increases in Arctic Ocean primary production, Prog. Oceanogr. 136: 60-70.

Castellani, C. (2009). Plankton: A Guide to their Ecology and Monitoring for Water Quality. Edited by Ian M. Suthers and David Rissik, CSIRO Publishing (Australia). 272pp. ISBN: 9780643090583

Cloern, J. E., Foster, S. Q; Kleckner, A. E. (2014). Phytoplankton primary production in the world's estuarine-coastal ecosystems; Biogeosciences, 11: 2477-2501.

Compère P. (1976a). Algues de la Région du Lac Tchad: Chlorophycophytes. Cah. O.R.S.T.R.O.M., sér. Hydrobiol. 10(2): 77 - 118.

Compère P. (1976b). Algues de la Région du Lac Tchad: Chlorophycophtes. Cah. O.R.S.T.R.O.M., sér. Hydrobiol. 10(3): 135 - 164.

Compère P. (1977). Algues de la Région du Lac Tchad: Chlorophycophytes. Cah. O.R.S.T.R.O.M., sér. Hydrobiol. 11(2): 77 - 117.

Costanza, R., Arge, G., Rudolf, F.; Belt, M. (1997): The value of the world's ecosystem services and natural capital. Nature, 387: 253-260.

Durrieu, C., Guedri, H., Fremion, F.; Volatier, L. (2011). Unicellular algae used as biosensors for chemical detection in the Mediterranean lagoon and coastal waters. Res. Microbiol., 162: 908-914

Davies. O. A, Abowei, J.F.N.; Tawari, C.C. (2009). Phytoplankton Community of Elechi Creek, Niger Delta, Nigeria-A Nutrient-Polluted Tropical Creek; Am. J. Appl. Sc. 6 (6): 1143-1152.

Ewebiyi. F.O., Appah. J.; Ajibade. G.A. (2015). Taxonomy, Distribution and Diversity of phytoplankton in some water bodies in Kaduna Metropolis, Nigeria. J. Nat. Sci. Res. 5(15): 22250921

Field, C. B., Behrenfeld, M. J., Randerson, J. T.; Falkowski, P. (2007): Primary production of the 
biosphere: integrating terrestrial and oceanic components. Science, 281(5374): 237-240.

Hendey, N. I. (1964). An introductory account of the smaller algae of British coastal waters. Part 5: Bacillariophyceae (Diatoms). In: Ministry of Agriculture, Fisheries and Food. Fishery Investigations series IV. HMSO, London. 317pp.

Karentz, D.; McIntire, C. D. (1977). Distribution of diatoms in the plankton of Yaquing Estuary, Oregon. J. Phycology. 13: $379-388$.

Kelly M.G., Juggins S., Bennion H., Burgess A., Yallop M., Hirst H., King L., Jamieson B.J., Guthrie R.; Rippey B., (2008). Use of diatoms for evaluating ecological status in UK freshwaters, Science Report: SC030103/SR4; Environment Agency, Rio House, Waterside Drive, Aztec West, Almondsbury, Bristol, BS32 4UD

Maranon, E. (2010); Phytoplankton Size Structure. Encyclopaedia of Ocean Sciences, University of Vigo; DOI: 10.1016/B978-012374473-9.00661-5

Margalef, D. R. (1960). Temporal succession and spatial heterogeneity in phytoplankton. In: Perspectives in Marine Biology. Buzzati Traverse, A. A. (Ed.). $323-343$ pp.

Ogbeibu, A. E. (2005). Biostatistics: A practical Approach to Research and Data Handling. Mindex Publishing Company Limited, Benin City. 264pp.

Onyema, I. C; Otudeko O.G; Nwankwo D.I. (2013). The distribution and composition of plankton around a sewage disposal site at Iddo, Nigeria. J. Sci. Res. Develop. 2003; 7: 11-26
Onyema, I.C. (2007). The phytoplankton composition, abundance and temporal variation of a polluted estuarine creek in Lagos, Nigeria. Turkish Journal of Fisheries and Aquatic Sciences, 7: 89-96.

Opute, F.I.; Kadiri, M.O. (2013). Phytoplankton algae of Nigeria; A practical and theoretical guide. Mindex Publishing Co. Ltd. ISBN 978-978-844876-1

Platt, T.; Denman, K. (1975); Coherences in the horizontal distributions of phytoplankton and temperature in the upper ocean. Mem. Soc. R. Sci. Liege 6th Ser. 7: 19-30

Thurman, H.V. (2007). Introductory Oceanography. Academic Internet Publishers. ISBN 978-1-42883314-2

Varadharajan, D.; Soundarapandian, P. (2014): Effect of physico-chemical parameters on species biodiversity with special reference to the phytoplankton from Muthupettai, South East Coast of India. J. Earth Sci. Clim. Change, 5(5): $1-10$.

Wassmann, P.; Duarte,C.M.; Agusti,S.; Sejr, M.K. (2011). Footprints of climate change in the Arctic marine ecosystem, Glob. Change Biol., 17: 12351249.

Wehr, J.D.; Descy, J.P. (1998). Use of phytoplankton in large river management. J. Phycol., 34: 741749.

Whitford, L. A., and G. J. Schumacher. (1973). A Manual of Freshwater Algae. Sparks press

Winpenny, R. S. (1966). The Plankton of the Sea. Faber and Faber Limited, London. 426pp. 